
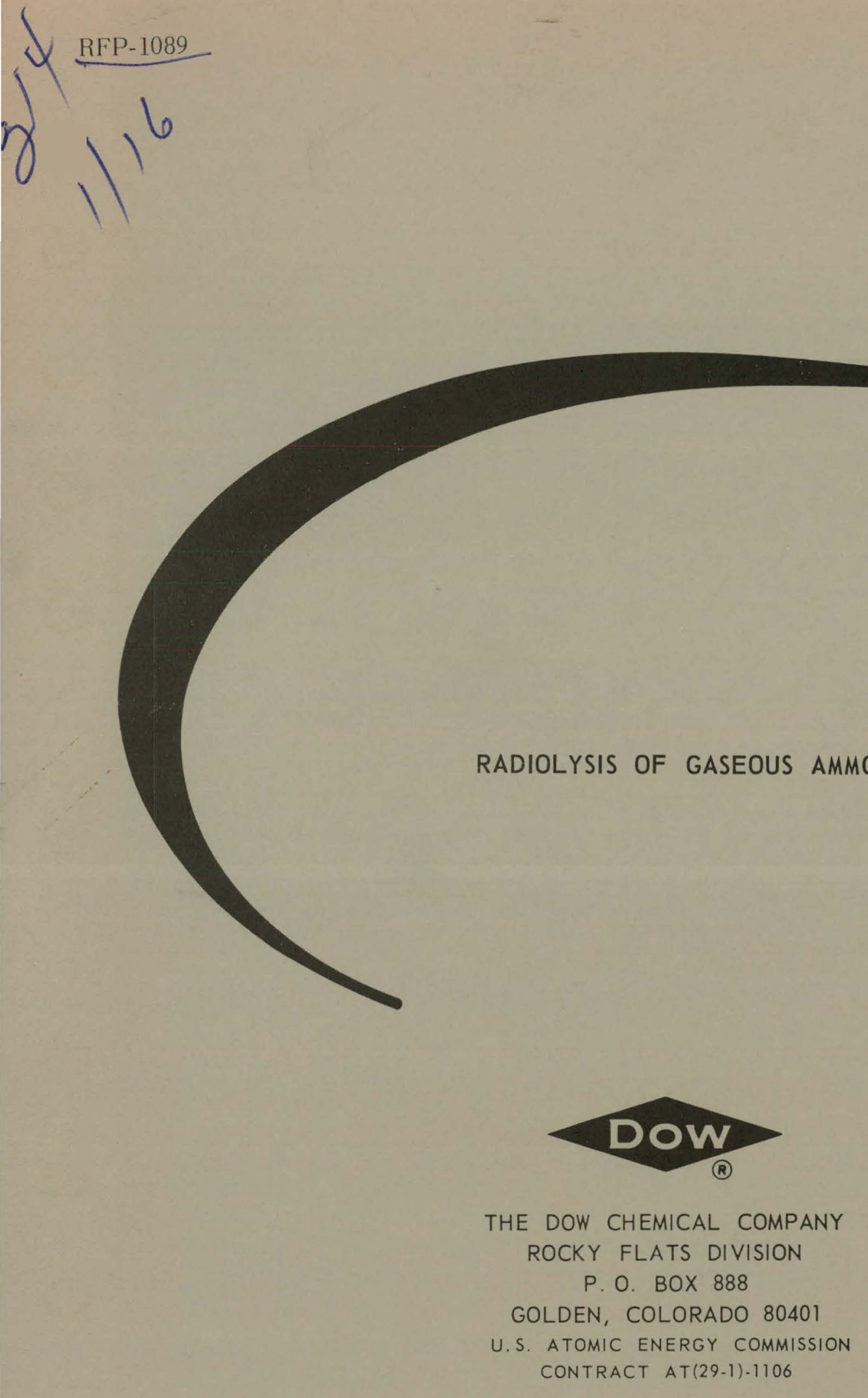


\section{DISCLAIMER}

This report was prepared as an account of work sponsored by an agency of the United States Government. Neither the United States Government nor any agency Thereof, nor any of their employees, makes any warranty, express or implied, or assumes any legal liability or responsibility for the accuracy, completeness, or usefulness of any information, apparatus, product, or process disclosed, or represents that its use would not infringe privately owned rights. Reference herein to any specific commercial product, process, or service by trade name, trademark, manufacturer, or otherwise does not necessarily constitute or imply its endorsement, recommendation, or favoring by the United States Government or any agency thereof. The views and opinions of authors expressed herein do not necessarily state or reflect those of the United States Government or any agency thereof. 


\section{DISCLAIMER}

Portions of this document may be illegible in electronic image products. Images are produced from the best available original document. 


\section{LEGAL NOTICE}

This report was prepared as an account of Government sponsored work. Neither the United States, nor the Commission, nor any person acting on behalf of the Commission:

A. Makes any warranty or representation, expressed or implied, with respect to the accuracy, completeness, or usefulness of the information contained in this report, or that the use of any information, apparatus, method, or process disclosed in this report may not infringe privately owned rights; or

B. Assumes any liabilities with respect to the use of, or for damages resulting from the use of any information, apparatus, method, or process disclosed in this report.

As used in the above, "person acting on behalf of the Commission" includes any employee or contractor of the Commission, or employee of such contractor, to the extent that such employee or contractor of the Commission, or employee of such contractor prepares, disseminates, or provides access to, any information pursuant to his employment or contract with the Commission, or his employment with such contractor.

Printed in the United States of America

Available from

Clearinghouse for Federal Scientific and Technical Information

Natimal Burean of Standards, U. S. Depastmenl of Cummerce

Springfield, Virginia 22151

Price: Printed Copy $\$ 3.00 ;$ Micr of iche $\$ 0.65$ 
Nuvember 22, 1968

RFP.1089

UC-4 CHEMISTRY

TID- 4500

\title{
RADIOLYSIS OF GASEOUS AMMONIA
}

\author{
Armen R. Kazaniian
}

Alon K. Brown

(.)

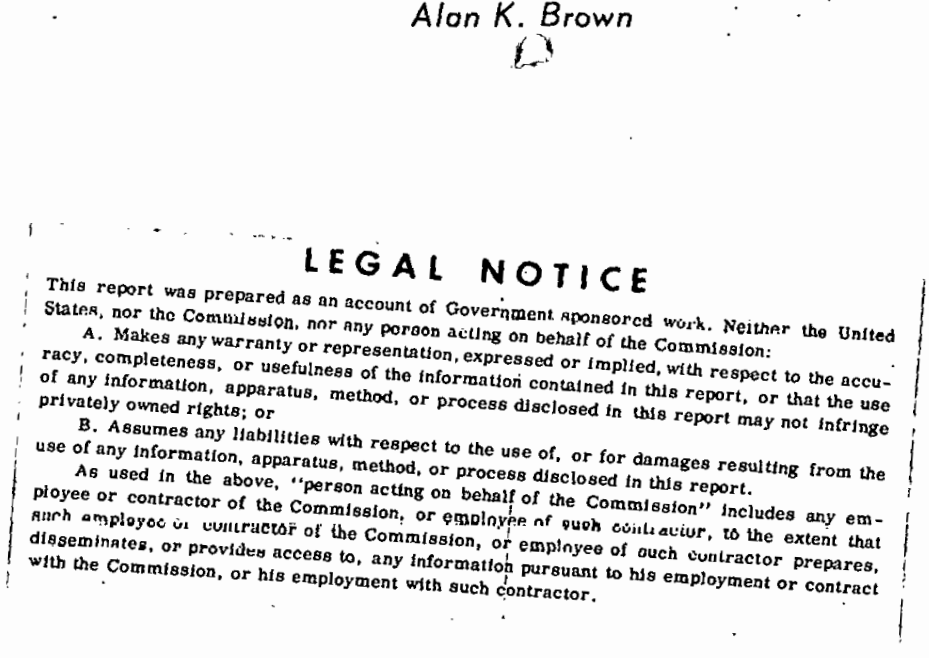

\footnotetext{
THE DOW CHEMICAL COMPANY ROCKY FLATS DIVISION

P. O. $80 \times 888$

GOLDEN, COLORADO 80401

U. S. ATOMIC ENERGY COMMISSION CONTRACT AT(29-1)-1106
} 
RFP-1089 


\section{CONTENTS}

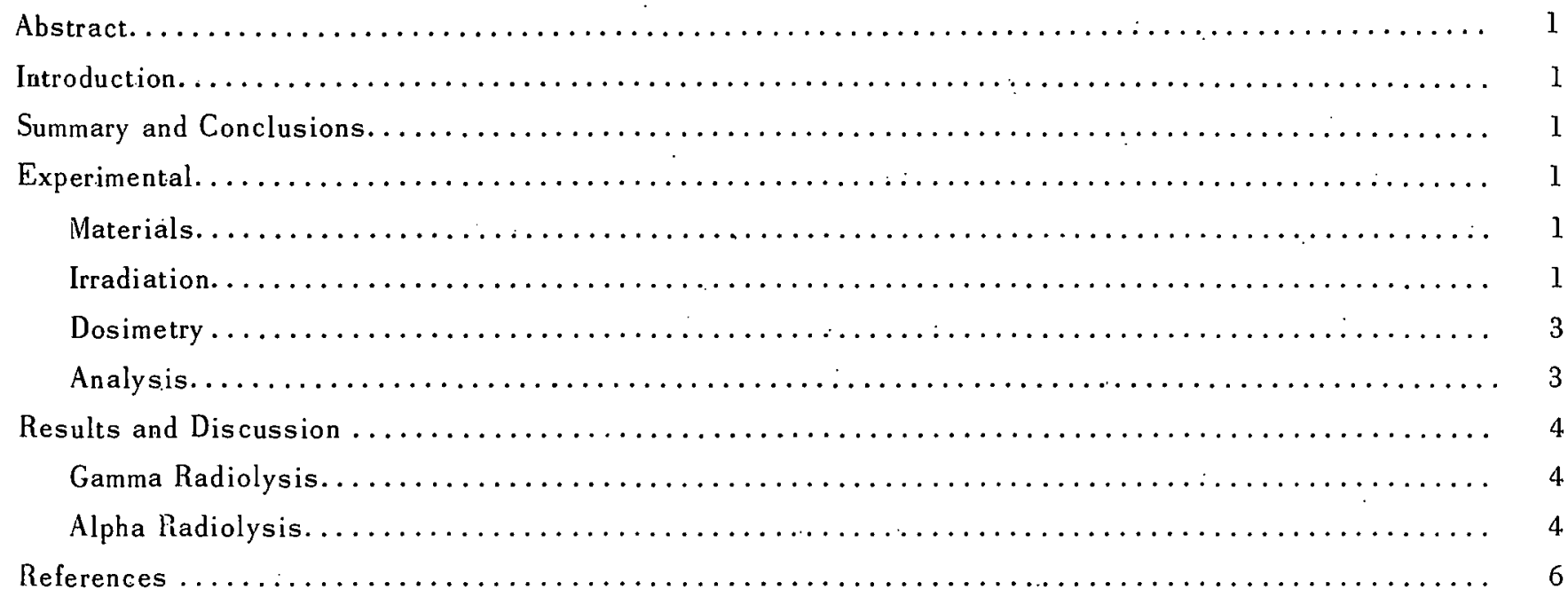


RFP- 1089

\section{ACKNOWLEDGMENT}

We grcatly appreciate the services of Mrs. Cary Chambers who performed all of the mass spectrometric analyses. 
RFP-1089

\title{
RADIOLYSIS OF GASEOUS AMMONIA
}

\author{
Armen R. Kazanjian and Alan K. Brown
}

Abstract. Ammonia was irradiated by alpha particles and gamma rays, and $G$ values for ammonia decomposition were $3.5 \pm 0.2$ for alpha radiolysis and $4.0 \pm 0.2$ for gamma radiolysis. The difference. in yields can be attributed either to the difference in linear energy transfer (LET) or the difference in radiation intensity, both of which are unusual effects in gas phase radiolysis.

\section{INTRODUCTION}

The radiolysis of gaseous ammonia has been investigated under a variety of conditions using alpha particles, gamma rays, energetic electrons and reactor pile neutrons (1-17). $\Lambda$ review of this work shows differences in the $G$ values, ${ }^{*}$ particularly in the irradiation by alpha sources. Furthermore, there is no explanation for the differences in the radiolytic yields resulting from the various sources of irradiation. This work is an attempt to establish reliable $G$ values for the decomposition of gaseous ammonia exposed to alpha particles and gamma rays and to explain the difference in radiolytic yield, if any. This investigation has the advantage over the previous ones in that more accurate chemical dosimetry $\left(\mathrm{N}_{2} \mathrm{O}\right)$ has been established for the irradiation sources.

\section{SUMMARY AND CONCLUSIONS}

Ammonia at 600 torr pressure was gamma irradiated in a Gammacell (B) containing about 4400 curies of ${ }^{60} \mathrm{Co}$ and alpha irradiated in a steel chamber containing three 10 -curie ${ }^{210} \mathrm{Po}$ sources. Nitrous oxide was used to determine the dose rates produced by these sources. The values were $1.2 \cdot 10^{16} \mathrm{eV} / \mathrm{ml} \cdot \mathrm{hr}$ in the Gammacell and $1.5 \cdot 10^{17} \mathrm{eV} / \mathrm{ml} \cdot \mathrm{hr}$ in the alpha cell. Products were analyzed with a Bendix mass spectrometer. Hydrogen and nitrogen were the only products detected.

* G value - The uumber uf inulecules produced or consumed peir $100 \mathrm{eV}$ of absorbed entergy.
The $G$ values for hydrogen production by gamma irradiation and by alpha irradiation were $6.0 \pm 0.3$ and $5.2 \pm 0.3$, respectively. This difference in yield could be attributed to either the difference in linear energy transfer (LET) or the difference in radiation intensity. Examples of the latter effect in gas phase radiolysis are very rare, while this may be the first example of an LET effect in gases.

\section{EXPERIMENTAL}

Materials: Matheson anhydrous ammonia with a minimum purity of 99.99 percent was used. Before irradiation the ammonia was frozen in liquid nitrogen and was evacuated to remove noncondensable gases. Matheson nitrous oxide, with a minimum purity of 98 percent, was used for the dosimetry. It was further purified by condensing in liquid nitrogen and evacuating to remove oxygen and nitrogen and then distilling from a dry ice ethanol bath to separate the $\mathrm{NO}_{2}$. The final product had a purity of at least 99.8 percent and $\mathrm{O}_{2}$ and $\mathrm{NO}_{2}$ impurities were less than 0.1 percent as determined by mass spectrometry.

Irradiation: The gamma irradiations were carried out in a Gammacell 220 (B), see Figure 1. This source, containing 4400 curies of ${ }^{\circ} \mathrm{Co}$ was made by Atomic Energy of Canada, Limited. Samples were irradiated in break-seal tubes of Pyrex about $8 \mathrm{~cm}$ in length with a volume of approximately $12 \mathrm{~cm}^{3}$. The gases were sealed into these tubes to eliminate the need for greased stopcocks.

The alpha radiolyses were carried out in a stainless steel chamber that contained three 10-curie polonium210 sources, as shown in Figure 2. These sources, fabricated by the Monsanto Research Corporation, are approximately 11 percent efficient, i.e., about 11 percent of the total radiative energy is transmitted through the thin stainless steel window that houses the ${ }^{210} \mathrm{Po}$. The dimensions of the hemispherical irradiation chamber (diameter-8 inches) and the gas pressures used (600 torr) were such that the alpha particlea werc completcly aboorbed in the irradiated gas. 


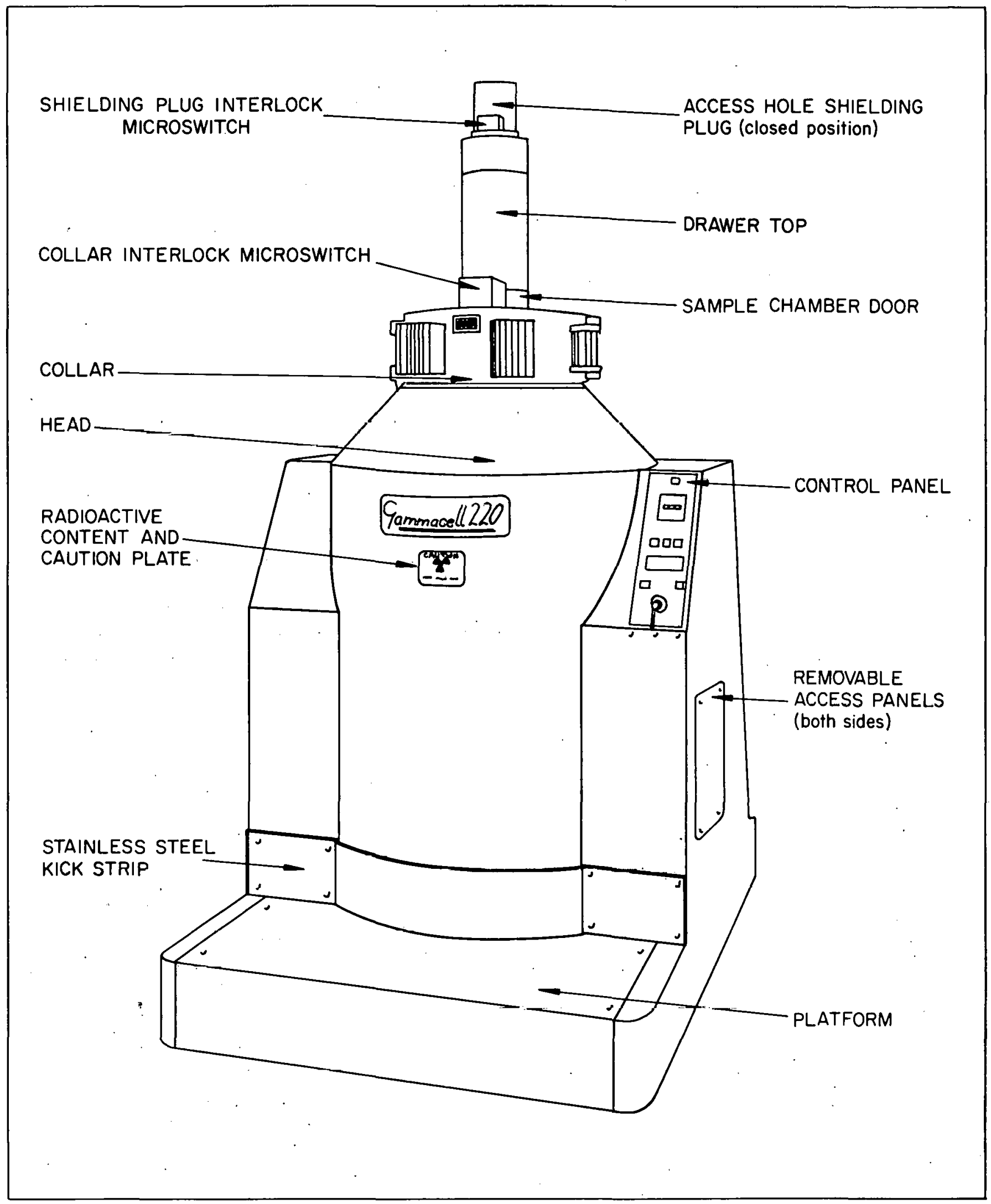

Figure I. Overall view of Gammacell 220. 


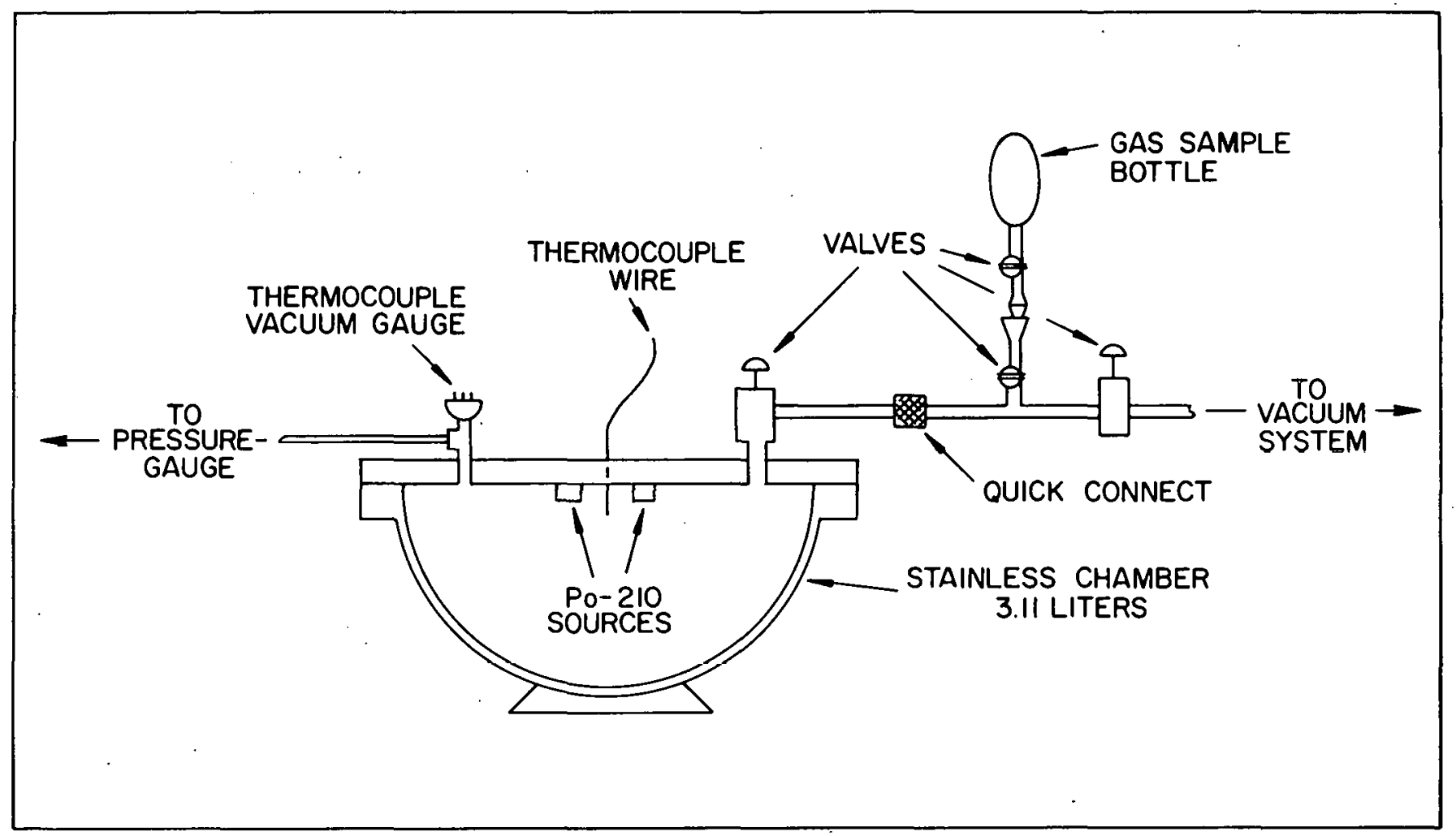

Figure 2. Radiolysis reaction chamber and gas sampling system.

Dosimetry: The dose rate in the Gammacell was determined both by $\mathrm{N}_{2} \mathrm{O}(\mathrm{g})$ dosimetry and by $\mathrm{FeSO}_{4}$ solution (Fricke) dosimetry. The value determined by the Fricke method was 20 percent higher than that measured by the $\mathrm{N}_{2} \mathrm{O}$ dosimeter, but was not considered as reliable because of the assumptions that have to be made in the conversion of the energy absorbed in a liquid to that absorbed in a gas. Dose conversions for different materials can be made simply by correcting for electron density in those cases where: (a) energy absorption is by the Compton process, and (b) the sample is in electronic equilibrium, i.e., when the irradiated material is surrounded by a similar substance such that there are as many electrons scattered out of the sample material as there are electrons scattered into it from the surrounding substance.

The first condition was satisfied in this work; however, electronic equilibrium was probably not achieved in gas irradiations. Errors in the conversion calculation from $\mathrm{N}_{2} \mathrm{O}(\mathrm{g})$ to $\mathrm{NH}_{3}(\mathrm{~g})$ would probably cancel hecause of the ir similar density, whereas there would be an error in the conversion of doses between $\mathrm{FeSO}_{4}$ solution and $\mathrm{NH}_{3}(\mathrm{~g})$.
The dose rate in the alpha cell was determined by $\mathrm{N}_{2} \mathrm{O}$ dosimetry before and after the ammonia irradiations. The $\mathrm{N}_{2} \mathrm{O}$ pressure was 660 torr and the dose rate was based on a $G\left(N_{2}\right)$ of 10.0 . There is some question about this value at large conversions (18-23) and the reason for this choice is discussed later.

Analysis: $\mathrm{All} \mathrm{N}_{2} \mathrm{O}$ and $\mathrm{NH}_{3}$ decomposition products were analyzed with a Bendix Time-of-Flight (Model 12) mass spectrometer. The irradiated gas was condensed in liquid nitrogen, the total pressure of uncondensed gases was measured with a MKS Baratron and then the ratios of these uncondensed gases were determined in the mass spectrometer. The relative standard deviation of these measurements was estimated to be 2 percent.

The analyses could also be made by bleeding the irradiated gases directly into the mass spectrometer. The results obtained this way were not as accurate but it was necessary to examine the condensable products, in particular hydrazine formed in the radiolys is of ammonia. 


\section{RESULTS AND DISCUSSION}

Gamma Radiolysis: The dose rate in the tubes of Pyrex, as determined by $\mathrm{N}_{2} \mathrm{O}$ at 600 torr pressure, was $2.6 \cdot 10^{16} \mathrm{eV} / \mathrm{ml} \cdot \mathrm{hr}$. This value was converted to the dose rate in ammonia by correcting for electron density. ${ }^{24}$

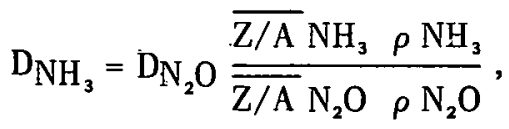

where $\mathrm{D}=$ dose rate

$$
\rho=\text { density }
$$

$$
\begin{aligned}
\overline{\mathrm{Z} / \mathrm{A}}= & \text { mean atomic number to atomic weight } \\
& \text { ratio }=\Sigma \mathrm{wi}(\mathrm{Z} / \mathrm{A}) \mathrm{i}
\end{aligned}
$$

where $w i=$ weight fraction of the $i^{\text {th }}$ element in the compound

The dose rate in ammonia at 600 torr pressure as determined by the above equation was $1.18 \cdot 10^{16}$ $\mathrm{eV} / \mathrm{ml} \cdot \mathrm{hr}$. Samples were irradiated up to 170 hours and the $\mathrm{G}$ values for $\mathrm{NH}_{3}$ decomposition remained constant throughout as can be seen in Figure 3 . The average $G$ values were $6.0 \pm 0.3$ for the $H_{2}$ yield and $2.0 \pm 0.2$ for the $N_{2}$ yield. Since no other products were formed (e.g., $\left.\mathrm{N}_{2} \mathrm{H}_{4}\right),{ }^{*} . \mathrm{G}\left(-\left[\mathrm{NH}_{3}\right)\right.$ was $4.0 \pm 0.2$ from stoichiometry, $2 \mathrm{NH}_{3} \rightarrow \mathrm{N}_{2}+3 \mathrm{H}_{2}$.

'I'hese results are compared with those from previous investigations and are shown in Table I. The results obtained in this work are equal to the average of the two previous ${ }^{60} \mathrm{Co}$ experiments. The results of other types of irradiation were also included for comparison because of . the ir similarity to gamma radiation. The tracks of the energetic electrons or protons [produced by neutron-hydrogen collisions or the ${ }^{14} \mathrm{~N}(\mathrm{n}, \mathrm{p}){ }^{14} \mathrm{C}$ reaction] are almost identical to those of electrons produced by the Compton process, particularly in the gas phase. Therefore, the $G$ values should be and are essentially the same for these types of irradiation.

Alpha Radiolysis: The conversion of dose rates from one material to another in the alpha cell is greatly simplified by the fact that the energy of

\footnotetext{
* The smallest $G$ value that could be detected because of
} analytical limitations was 0.1 .

\begin{tabular}{|c|c|c|c|c|}
\hline Radiation & $\mathrm{G}\left(\mathrm{H}_{2}\right)$ & $\mathrm{G}\left(\mathrm{N}_{2}\right)$ & $\mathrm{G}\left(-\mathrm{NH}_{3}\right)$ & Reference \\
\hline$y^{60}{ }^{60}$ & 6.0 & 3.0 & {$[4.0]$} & thio wopk \\
\hline$\gamma,{ }^{60} \mathrm{Co}$ & {$[4.9]$} & - & 3.27 & 2 \\
\hline$\gamma,{ }^{\infty} \mathrm{Co}$ & 7.0 & 2.3 & {$[4.66]$. } & 4 \\
\hline $5 \mathrm{keV}$ electronons & 0.18 & 2.10 & {$[4.12]$} & 3 \\
\hline $100 \mathrm{ev}$ electrons & 8.8 & 2.9 & {$[5.86]$} & 5 \\
\hline pile neutron & {$[5.2]$} & - & 3.5 & 1 \\
\hline
\end{tabular}

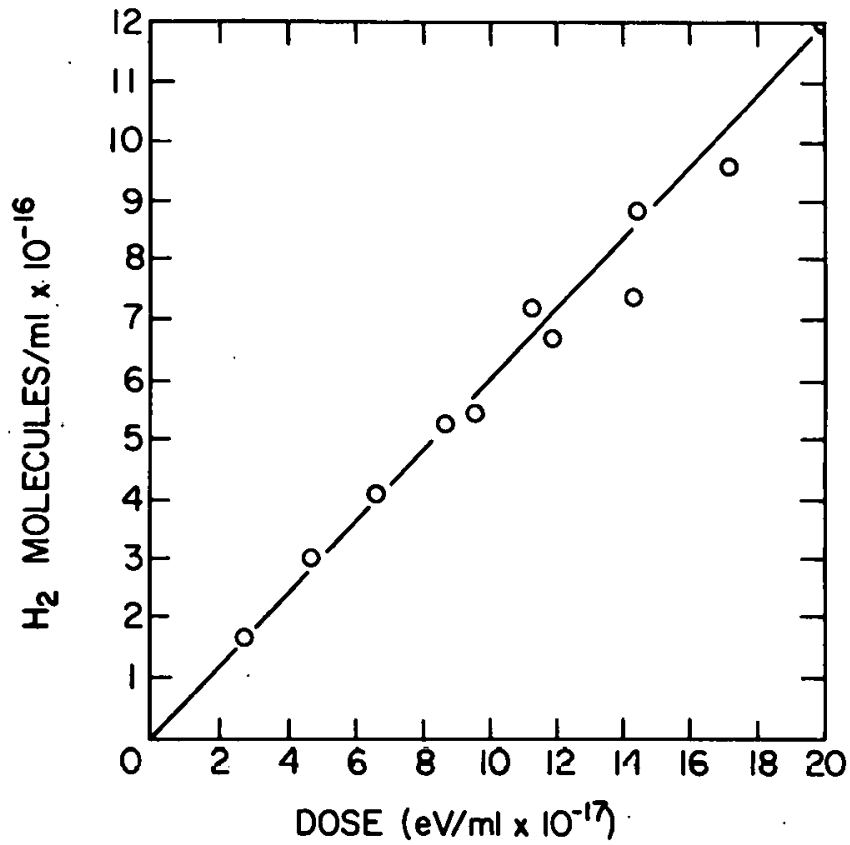

Figure 3. Gamma radiolysis, product yield versus dose.

Table I. Gamma radiolysis of ammonia.

NOTE: The values in brackets are calculated assuming $\mathrm{H}_{2}$ and $\mathrm{N}_{2}$ are the only products.

the alpha particle is entirely dissipated in the gas. At 600 torr ammonia pressure the range of a ${ }^{210} \mathrm{Po}$ alpha particle is $3.7 \mathrm{~cm}$ and the radius of the hemispherical alpha chamber is $10 \mathrm{~cm}$. The dose rate, as determined by $\mathrm{N}_{2} \mathrm{O}$ dosimetry, was approximately $1.5 \cdot 10^{17} \mathrm{eV} / \mathrm{ml} \cdot \mathrm{hr}$. The polonium$210(t / 2=138 d)$ decayed appreciably during the course of these experiments so the dose rate was adjusted accordingly.

As mentioned in the experimental section, both the alpha and gamma dose rates were calculated using a $G\left(N_{2}\right)$ value of 10.0 . The $G$ value has never been determined for alpha radiation, although $\mathrm{N}_{2} \mathrm{O}$ has been irradiated with x-ràys, $\gamma$-rays, neutrons and fission fragments. The yields were essentially 
identical $(18-23)$ so the same yield $(G=10.0)$ would be expected for alpha irradiation. There is some question about this value particularly at the higher doses (or higher conversions) where the $\mathrm{N}_{2}$ yield is known to decrease (20-22). Although the $\mathrm{N}_{2} \mathrm{O}$ was irradiated to an extent where the decrease in $\mathrm{G}\left(\mathrm{N}_{2}\right)$ has been reported $(21,22)$ to begin, there was no indication of a decrease throughout the range from 0.1 to 1.5 percent conversion. A review of $\mathrm{N}_{2} \mathrm{O}$ dosimetry has been made by Lampe et al. (23) who recommend using a $\mathrm{G}\left(\mathrm{N}_{2}\right)$ of 10.2 at low dose rates although there are higher reported values. These factors have led to the choice of 10.0 , but it is conceivable that a 10 percent error could be introduced because of this uncertainly.

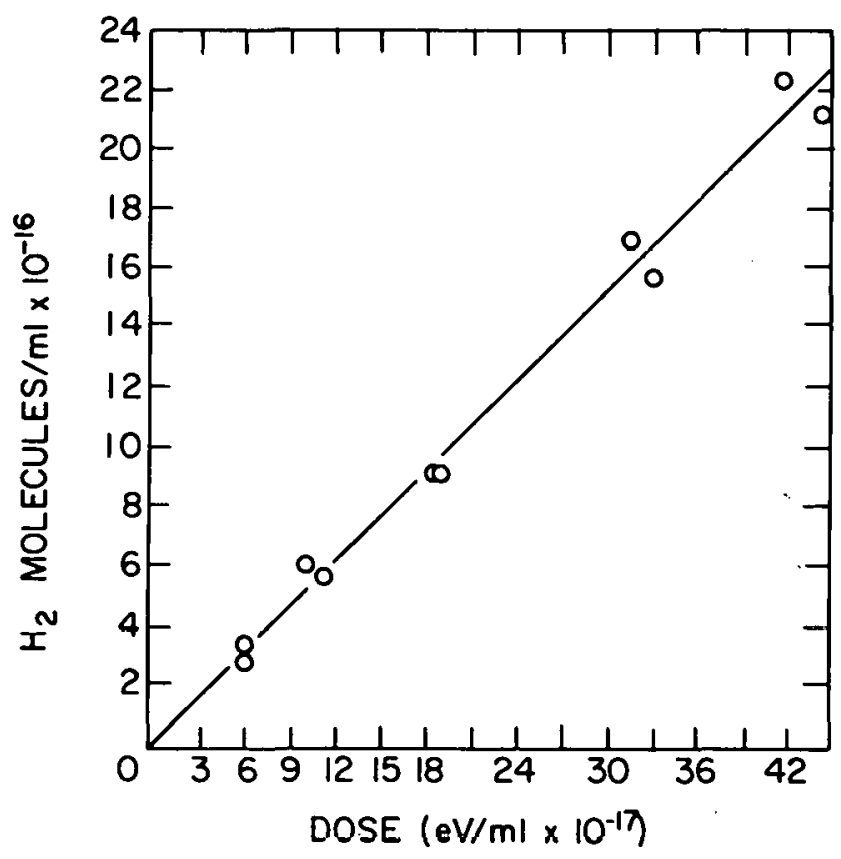

Figure 4. Alpha radiolysis, product yield versus dose.

The radiolytic decomposition of ammonia was extended to 1.5 percent conversion and the everage $\mathrm{G}\left(\mathrm{H}_{2}\right)$ was determined to be $5.2 \pm 0.3$. Figure 4 shows that this value was constant over the entire dose range. As with gamma radiolysis, products other than $\mathrm{H}_{2}$ and $\mathrm{N}_{2}$ were not detected so that the other $\mathrm{G}$ values could be calculated by stoichiometry. The $\mathrm{H}_{2} / \mathrm{N}_{2}$ ratios were approximately three, and since the $\mathrm{N}_{2}$ analyses appeared much less accurate than the $\mathrm{H}_{2}$ analyses, the $\mathrm{N}_{2}$ yield was calculated from the $\mathrm{H}_{2}$ yield by stoichiometry. $\mathrm{G}\left(\mathrm{N}_{2}\right)$ was 1.7 and $\mathrm{G}\left(-\mathrm{NH}_{3}\right)$ was $3.5 \pm 0.2$. This value is close to the average of those obtained from the other investigations as shown in Table II.

\begin{tabular}{|c|c|c|c|}
\hline $\mathrm{G}\left(-\mathrm{NH}_{3}\right)$ & $\mathrm{G}\left(\mathrm{H}_{2}\right)$ & $a$-Source & Ŕeference \\
\hline 3.5 & 5.2 & Po & this work \\
\hline 3.1 & - & $\mathrm{Ra}$ & 6 \\
\hline 3.2 & - & Rn & 7 \\
\hline 4.1 & - & $R_{n}$ & 9 \\
\hline 3.6 & - & $\mathrm{Ra}$ & 11 \\
\hline 4.5 & - & $\mathrm{Ra}$ & 12 \\
\hline 3.2 & - & $\mathrm{Ra}$ & 15 \\
\hline 3.7 & _- & $\mathrm{Ra}$ & 17 \\
\hline
\end{tabular}

NOTE: All the earlier results were expressed in terms of ion yields, i.e., the number of molecules decomposed (M) per ion pair produced $(N)$. These were converted to $G$ values using the expression $G=M / N(100 / W)$ where $W$ (the energy required to from an ion pair in $\mathrm{NH}_{3}$ ) is $30.5 \mathrm{eV}$ (25).

The previous investigations can be conveniently grouped into two different methods as shown in Table II. The first three in the reference column (No. 6, 7,9) were very similar studies in which radon (homogeneously mixed or contained in a glass sphere) or radium salts were used as alpha sources. The disadvantage is that the dosimetry (in terms of ion pairs produced) is very difficult to calculate accurately. In fact, the oldest results (6) are merely reported as molecules of ammonia decomposed per curie of radium used. Jungers (7), however, recalculated these values in terms of molecules decomposed per ion pair produced.

The main difficulty in this early work lies in assessing the location and contribution of the radioactive decay products. This problem is eliminated using radon in thin-glass spheres, but here there is a problem estimating the alpha energy transmitted through the nonuniform glass walls. The sources in the glass sphere were sometimes calibrated using chemical dosimeters of questionable accuracy.

Another serious defect in all of the earlier work is that the radiolyses were carried on to very high conversions (from 5 to 30 percent). This was necessary in order to make accurate pressure mcasurements of the noncondensable gases. These conditions, with the high probability of back reactions, can not be compared with the usual radiation studies where the initial stages are of prime concern. 
The last four references (Table II) were likewise very similar and were written by persons working in the same laboratory. The authors have used the ion-saturation method. This method utilizes the irradiation flask as an ionization chamber in which the number of ion pairs produced is determined by measuring the ion current collected on a pair of oppositely charged plates. The disadvantage of this method is that very low irradiation intensities must be used, about one-thousandth of that produced by the polonium-210 source used in this work. This fact is significant because the ion yield varies with intensity as shown by Burtt and his coworkers $(17,19)$ and Luyckx $(9)$. Burtt and his coworkers found that the ion yield increased slightly with increasing intensity. 'These intensities were relatively low and if their results were extrapolated to the ${ }^{210} \mathrm{Po}$ intensities used in this work the increase in ion yield would be appreciable. Luyckx (9), using intensities similar to that of our ${ }^{210} \mathrm{Po}$ source, found, to the contrary, that the ion yield decreased about 30 percent with a fiftyfold increase in intensity. This latter conclusion is in agreement with our studies.

A significant result of this investigation is that the $G$ values from gamma decomposition are approximately 13 percent higher than the $G$ values from alpha decomposition. It is generally agreed (26) that different types of radiation should make little or no difference in the radiolysis of gases because the difference in LET* in the vapor phase is of little consequence. This is due to the ability of the active species (ions or radicals) to migrate rapidly from their tracks thereby eliminating the chance for recombination reactions. However, special studies have not been made to investigate this point, and ammonia could be an exception.

The difference in $G$ values could be attributed to either the difference in LET or the intensity, since the dose rate in the alpha cell was 10 times larger than that in the Gammacell $\left(1.5 \cdot 10^{17} \mathrm{eV} / \mathrm{ml} \cdot \mathrm{hr}\right.$ versus $1.2 \cdot 10^{16} \mathrm{eV} / \mathrm{ml} \cdot \mathrm{hr}$ ). However, the difference in LET between an alpha particle and a high energy electron produced by a gamma photon is at least a factor of 100 . Since LET effects and intensity effects are essentially identical phenomena (27), and the LET difference between the ionizing particles is greater than 10 times the intensity difference,

\footnotetext{
* Linear Energy Transfer - The amount of energy dissipated by an ionizing particle per unit distance along its track; usually expressed as keV per $\mu$.
}

the disparity in product yield could be due mainly to the LET effect.

This explanation would still be compatible with the findings of Luyckx (9) that the ion yield decreased with intensity. The overall interpretation is the following: There should be no intensity effects with gamma irradiation as the active species are too distant in gases to recombine. This would also be true with the very low alpha intensities used in the ion-saturation method studies. However, when alpha intensities on the order of $10^{17} \mathrm{eV} / \mathrm{ml} \cdot \mathrm{hr}$ are used, a fraction of the active species are sufficiently close to recombine and prevent the formation of molecular products. Using greater intensities, as Luyckx did, will result in still smaller yields as the alpha radiation tracks will tend to overlap to a greater extent. The only other examples of this effect in gas phase radiolysis are the $\mathrm{H}_{2} \mathrm{~S}$ investigations by Mund (28) and the $\mathrm{CO}$ investigation by Anderson (29) who also found a decrease in product yield with an increase in dose rate.

Further confirmation of this interpretation is provided by the results of the gamma radiolys is of liquid ammonia (30-32). Under these conditions of approximately a thousand-fold increase in density and therefore irradiation intensity, one would expect a large decrease in yield compared to that in the gas phase because of recombination reactions. This is in fact true as $G$ values on the order of a few tenths were obtained (30-32).

The problem has not been completely resolved by the results on these experiments. One way to verify the above explanation experimentally would be to decrease the intensity of our ${ }^{220} \mathrm{Po}$ source or perhaps decrease the ammonia pressure in the chamber and note whether the $G$ values approach those of gamma irradiation.

\section{REFERENCES}

1. P. C. Davidge, Atomic Energy Research Establishment Report - C/R - 1569 (1955).

2. L. Dollé, Second Geneva Conf. 29, 367 (1958).

3. Y. Toi, D. Peterson, and M. Burton, Radiation Res., 17, 399 (1962).

4. Y. Sorokin and S. Pshezhetskii, Zh. Fiz. Khim., 38 (3) 798 (1964). 
5. C. E. Melton, J. Chem. Phys., 45, 4414 (1966).

6. E. Wourtzel, Compt. rend., 158, 571 (1914).

7. J. C. Jungers, Bull. Soc. Chim. Belg., 41, 377 (1932).

8. J. C. Jungers, J. Phys. Chem., 40, 155 (1936).

9. A. Luyckx, Bull. Soc. Chim. Belg., 43, 117 (1934).

10. lbid., p 160.

11. H. Essex and D. Fitzgerald, J. Am. Chem. Soc., 56, 65 (1934).

12. C. Smith and H. Essex, J. Chem. Phys., 6, 188 (1938).

13. M. McGuiness and H. Essex, J. Am. Chem. Soc., 64, 1908 (1942).

14. H. Essex, J. Phys. Chem., 58, 42 (1954)

15. B. Burtt and T. Baurer, J. Chem. Phys., 23, 466 (1955).

16. A. Zahlen and B. Burtt, J. Chem. Phys., 24, 478 (1956).

17. B. Burtt and A. Zahlen, J. Chem. Phys., 26, 846 (1957).

18. P. Harteck and S. Dondes, Nucleonics, 14, No. 3, 66 (1956).

19. J. Hearne and R. Hummel, Radiation Res., 15,254 (1961).
20. G. R. Johnson, J. Inorg. Nucl. Chem., 24, 461 (1962).

21. A. Anderson, J. Best, and D. Dominey, J. Chem. Soc., 3498 (1962).

22. F. Jones and T. Sworski, J. Phys. Chem., 70, 1546 (1966).

23. F. W. Lampe, L. Kevan, E. R. Weiner, and W. H. Johnston, "The Radiolysis of Nitrous Oxide as a Dosimeter," AEC Report JLI-2901-75 (1966).

24. J. Spinks and R. Woods, An Introduction to Radiation Chemistry, J. Wiley and Sons, New York (1964) p 94.

25. C. Biber, P. Huber, and A. Muller, Helvetica Physica Acta, 26, 602 (1953).

26. S. C. Lind, Radiation Chemistry of Gases, Reinhold Corporation, New York (1961) p 23.

27. W. Burns and R. Barker, Progr. Reaction Kinetics, 3, 303 (1965).

28. W. Mund, M. Schauwenaars, and K. Devriendt, Bull. Soc. Chim. Belg., 43, 431 (1934).

29. A. Anderson, J. Best, and M. Willett, to be published, results reported in ref. (27).

30. Y. Sorokin and S. Pshezhetskii, S. Dolkl. Akad. Nauk SSSR, 138, 880 (1961).

31. Y. Sorokin, V. Tsivenko, and S. Pshezhetskii, Zh. Fiz. Khim., 37, (8) 1871 (1963).

32. J. Belloni, J. Chim. Phys., 63, 1281 (1966). 